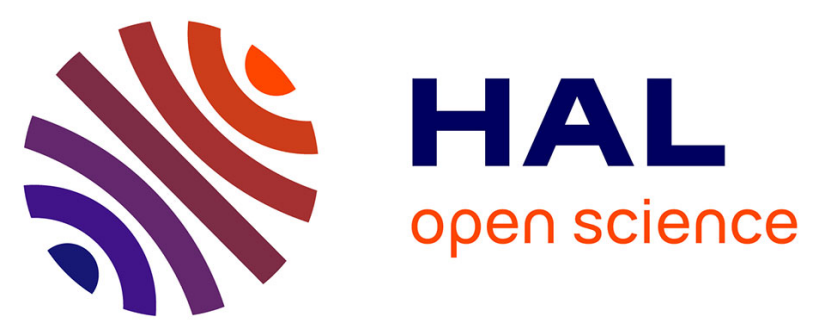

\title{
Prognostic utility of $\beta$-tubulin isotype III and correlations with other molecular and clinicopathological variables in patients with early breast cancer: a translational Hellenic Cooperative Oncology Group (HeCOG) study
}

George Pentheroudakis, Anna Batistatou, Konstantine T. Kalogeras, Ralf Kronenwett, Ralph M. Wirtz, Evangelos Bournakis, Anastasia G. Eleftheraki, Dimitrios Pectasides, Mattheos Bobos, Irini Papaspirou, et al.

\section{To cite this version:}

George Pentheroudakis, Anna Batistatou, Konstantine T. Kalogeras, Ralf Kronenwett, Ralph M. Wirtz, et al.. Prognostic utility of $\beta$-tubulin isotype III and correlations with other molecular and clinicopathological variables in patients with early breast cancer: a translational Hellenic Cooperative Oncology Group (HeCOG) study. Breast Cancer Research and Treatment, 2011, 127 (1), pp.179-193. 10.1007/s10549-011-1427-0 . hal-00620889

\section{HAL Id: hal-00620889 \\ https://hal.science/hal-00620889}

Submitted on 9 Sep 2011

HAL is a multi-disciplinary open access archive for the deposit and dissemination of scientific research documents, whether they are published or not. The documents may come from teaching and research institutions in France or abroad, or from public or private research centers.
L'archive ouverte pluridisciplinaire HAL, est destinée au dépôt et à la diffusion de documents scientifiques de niveau recherche, publiés ou non, émanant des établissements d'enseignement et de recherche français ou étrangers, des laboratoires publics ou privés. 
Prognostic utility of $\beta$-tubulin isotype III and correlations with other molecular and clinicopathological variables in patients with early breast cancer: A translational Hellenic Cooperative Oncology Group (HeCOG) study.

George Pentheroudakis, Anna Batistatou', Konstantine T. Kalogeras ${ }^{3,4}$, Ralf Kronenwett ${ }^{5}$, Ralph M. Wirtz ${ }^{5}$, Evangelos Bournakis ${ }^{6}$, Anastasia G. Eleftheraki ${ }^{7}$, Dimitrios Pectasides ${ }^{8}$, Mattheos Bobos ${ }^{9}$, Irini Papaspirou ${ }^{10}$, Sevasti Kamina ${ }^{2}$, Helen Gogas $^{11}$, Angelos K. Koutras ${ }^{12}$, Nicholas Pavlidis ${ }^{1}$, George Fountzilas ${ }^{3}$

${ }^{1}$ Department of Medical Oncology, Ioannina University Hospital, Ioannina, Greece; ${ }^{2}$ Department of Pathology, Ioannina University Hospital, Ioannina, Greece; ${ }^{3}$ Department of Medical Oncology, "Papageorgiou" Hospital, Aristotle University of Thessaloniki School of Medicine, Thessaloniki, Greece; ${ }^{4}$ Translational Research Section, Hellenic Cooperative Oncology Group, Data Office, Athens, Greece; ${ }^{5}$ Siemens Healthcare Diagnostics, Cologne, Germany; ${ }^{6}$ Department of Clinical Therapeutics, "Alexandra" Hospital, University of Athens School of Medicine, Athens, Greece; ${ }^{7}$ Hellenic Cooperative Oncology Group, Data Office, Section of Biostatistics, Athens, Greece; ${ }^{8} 2^{\text {nd }}$ Department of Internal Medicine, Oncology Section, “Hippokration" Hospital, University of Athens School of Medicine, Athens, Greece; ${ }^{9}$ Laboratory of Molecular Oncology, Hellenic Foundation for Cancer Research, Aristotle University of Thessaloniki School of Medicine, Thessaloniki, Greece; ${ }^{10}$ Histopathology Department, "Alexandra" Hospital, Athens, Greece; ${ }^{11} 1^{\text {st }}$ Department of Medicine, "Laiko" General Hospital, University of Athens School of Medicine, Athens, Greece; ${ }^{12}$ Department of Medicine, Division of Oncology, University Hospital, University of Patras Medical School, Patras, Greece.

Current address for Dr. Ralf Kronenwett: Sividon Diagnostics GmbH, Nattermann Allee 1, D-50829 Cologne, Germany

Current address for Dr. Ralph M. Wirtz: Stratifyer Molecular Pathology GmbH, Werthmannstrasse 1, D-50935 Cologne, Germany 
Key words: Breast cancer, $\beta$-tubulin isotype III, adjuvant chemotherapy, prognostic/predictive factors.

Address for correspondence

George Pentheroudakis

Department of Medical Oncology

Ioannina University Hospital

Niarxou Avenue

45500 loannina GREECE

Tel and fax 302651099394

e-mail: gpenther@otenet.gr 


\section{Abstract}

Background. We evaluated the prognostic and predictive utility of $\beta$-tubulin isotype III (TUBB3) tumour gene transcription in early breast cancer patients enrolled in a randomised study.

Patients and Methods. Quantitative reverse transcription-polymerase chain reaction (qRTPCR) was applied for assessment of TUBB3, ER, PgR, HER2, and MAPT messenger RNA and immunohistochemistry (IHC) for protein expression in 314 patients enrolled in trial HE10/97, evaluating epirubicin-alkylator adjuvant chemotherapy with or without paclitaxel.

Results. High TUBB3 mRNA status was associated with advanced T stage, high histologic grade, low mRNA and protein levels of ER, PgR and MAPT and high levels of HER2 ( $<<0.001)$. At a median follow-up of 98 months, multivariate analysis showed high TUBB3 mRNA status to have prognostic significance for DFS (HR=1.83, 95\% Cl 1.25-2.68, $\mathrm{p}=0.002)$ and $\mathrm{OS}(\mathrm{HR}=1.71,95 \% \mathrm{Cl} 1.03$ 2.83, $\mathrm{p}=0.038)$, along with the number of involved axillary nodes, PgR mRNA status and tumour grade. TUBB3 mRNA levels did not predict benefit from inclusion of paclitaxel in adjuvant chemotherapy (test for interaction $\mathrm{p}=0.96$ for $\mathrm{OS}, \mathrm{p}=0.46$ for DFS).

Conclusions. Transcriptional activity of $\beta$-tubulin isotype III in early breast cancer is an adverse prognostic factor, though not a predictive one for taxane efficacy. 


\section{Introduction}

Breast adenocarcinoma is the most common malignant neoplasm in females. As many as $60-70 \%$ of affected patients present with localised disease and become disease-free following surgical resection of the tumour, thus becoming candidates for adjuvant systemic therapy[1]. Several clinicopathological parameters, including tumour size, grade, hormonal receptor status, axillary nodal involvement, patient age, and Human Epidermal growth factor Receptor-type 2 (HER2) overexpression are taken into consideration in order to identify which patients are most likely to benefit from administration of adjuvant cytotoxic chemotherapy[2]. Still, individual patients may be under- or over-treated. Ultimately, we are unable to predict the true binary outcome of recurrence versus no recurrence at the level of the individual, as this simple clinicopathological profile does not capture the rich molecular heterogeneity of the malignancy.

Taxanes are natural products that disrupt the dynamic equilibrium of microtubule polymerisation and cause mitotic arrest and apoptosis of malignant cells. Data from 21 clinical trials of first-generation taxanes that were randomly allocated over 35,000 women with early-stage breast cancer to taxane-based versus taxane-free adjuvant therapies established a modest improvement in patient outcome[3]. This modest benefit was observed irrespective of the type of taxane, schedule of administration, extent of nodal involvement, and hormone-receptor status. Taxanes are associated with considerable side effects, often require the use of adjunctive medications and are expensive. Accordingly, controversy persists regarding their role in the adjuvant management of early-stage breast cancer, as a result of our inability to identify the subgroup of patients who would truly benefit. Consequently, the quest for tumoural molecular traits that have the potential to be useful predictive factors for taxane activity is justified.

Microtubules are intrinsically dynamic polymers composed of $\alpha \beta$-tubulin heterodimers and constitute essential components of the mitotic spindle and cytoskeleton. Microtubule dynamics control mitosis and cellular motility. Moreover, 
microtubules serve as scaffolds for signalling molecules and gene transcription regulators, for trafficking of cellular organelles as well as vesicles and for fine-tuning of cell cycle activity[4]. This dynamic network should be seen as polymers of tubulin dimers in flux, as it is in equilibrium with a repertoire of modulating factors, such as the $\alpha / \beta$ tubulin heterodimer ratio, the $\beta$-tubulin isotypes being integrated and the microtubule-associated proteins (MAP) attached. Altered tumoural expression of $\beta$ tubulin isotypes, which constitute the major microtubule proteins, may affect taxane binding and alter microtubule dynamics. At least eight different $\beta$-tubulin isotypes (classes I, II, III, IVa, IVb, V, VI and VII) have been identified[5]. In particular, it has been suggested that overexpression of class III $\beta$-tubulin (TUBB3) may destabilise microtubules and counteract the effects of taxanes. To date, the clinical data that predict taxane resistance in relation to class III $\beta$-tubulin expression in advanced breast cancer are unclear and this link has yet to be studied in the adjuvant setting[6]. Accordingly, we retrospectively studied the transcription and protein expression of TUBB3 in patients with resected high-risk breast cancer who had been randomised to receive adjuvant chemotherapy in the context of a prospective randomised Hellenic Cooperative Oncology Group (HeCOG) trial. The administration of taxane-based versus taxane-free chemotherapy regimens would allow us to dissect the prognostic versus predictive utility of TUBB3 expression. Moreover, we analysed correlations of TUBB3 expression with clinical, pathological and molecular characteristics of the tumour.

\section{Patients and Methods}

\section{Clinical Trial}

The HeCOG prospective trial HE10/97 randomised a total of 595 high-risk (T13N1M0 or T3NOMO) breast cancer patients in the period 1997-2000, to receive either four cycles of epirubicin followed by four cycles of intensified cyclophosphamide, methotrexate and 5-fluorouracil combination chemotherapy (E- 
CMF) or three cycles of epirubicin followed by three cycles of paclitaxel and three cycles of intensified CMF (E-T-CMF)[7]. Chemotherapy cycles were administered every 2 weeks and patients received granulocyte-colony stimulating factor (GCSF) support. The trial was approved from the Bioethics Committee of the Aristotle University of Thessaloniki and patients provided written informed consent prior to enrolment. All participating patients also gave written informed consent for research use of their biologic material.

\section{Molecular and Immunohistochemical Studies}

This was a retrospective translational research study among patients who had been enrolled in a prospective clinical trial ( A REMARK diagram is provided in Figure 1). Accordingly, collection of formalin-fixed paraffin-embedded (FFPE) tumour tissue samples was possible in 317 patients only, due to logistical/organisational barriers. Hematoxylin-eosin sections from all available FFPE tissue specimens were evaluated histologically by a certified pathologist and recorded for the percentage of tumor cell content. Prior to RNA isolation, macrodissection of tumour areas was performed for sections with $<50 \%$ tumor cell content.

Sufficient RNA was isolated from 314 FFPE specimens. In detail, from each FFPE section or macrodissected tissue fragments (10 $\mu \mathrm{m}$ thick) RNA was isolated using a fully automated isolation method for total RNA from FFPE tissue, based on silicacoated magnetic beads (Versant Tissue Preparation Reagents, Siemens Healthcare Diagnostics, Tarrytown, NY) in combination with a liquid handling robot, as previously described[8]. The method involves DNase I treatment for eliminating DNA contamination in the sample. Quantitative reverse transcription-polymerase chain reaction (qRT-PCR) was applied for the assessment of the $\beta$-tubulin type III (TUBB3) gene, which includes four exons and four introns, by using a gene specific Taq-Man based assay. The TUBB3 gene is situated at chromosome 16 at the genome locus 16q24.3. Forty cycles of nucleic acid amplification were applied and the cycle threshold (CT) value of the target gene was identified. CT values were normalized by subtracting the CT value of the housekeeping gene RPL37A from the CT value of the 
target gene $(\triangle C T)$. RNA results were then reported as $40-\Delta C T$ values, which would correlate proportionally to the mRNA expression level of the target gene.

Expression of the TUBB3 gene, as well as the reference gene RPL37A, was assessed in triplicate by qRT-PCR using the SuperScript III PLATINUM One-Step Quantitative RTPCR System with ROX (Invitrogen, Karlsruhe, Germany) in an ABI PRISM 7900HT (Applied Biosystems, Darmstadt, Germany)[9]. The lengths of the amplicons detected by the TUBB3 and RPL37A assays were $91 \mathrm{bp}$ and 65bp, respectively.

The Primer/Probe (FAM/TAMRA-labelled) sets used for amplification of the target and reference genes were the following $\left(5^{\prime}->3^{\prime}\right)$ :

TUBB3 Probe CGTGCACATCCAGGCCGGC

Forward Primer CAGACGCGCCCAGTATGAG

Reverse Primer TCACTGATGACTTCCCAGAACTTG

RPL37A Probe TGGCTGGCGGTGCCTGGA

Forward Primer TGTGGTTCCTGCATGAAGACA

Reverse Primer GTGACAGCGGAAGTGGTATTGTAC

The same experimental principles were used in order to study mRNA levels of the following genes: ESR1 (Estrogen Receptor), PgR (Progesterone Receptor), HER2 (Human Epidermal growth factor Receptor type 2, HER2), and MAPT ( MicrotubuleAssociated Protein Tau). Probes and primers used for the study of these genes are listed in Appendix 1. The quality and quantity of RNA was checked by measuring RPL37A expression as surrogate by qRT-PCR. Human reference total RNA pooled from ten human cell lines (Stratagene, La Jolla, California, USA) was used as a positive control. No-template-controls were assessed in parallel to exclude contamination. 
ER (clone 6F11, Leica Biosystems, Newcastle Upon Tyne, UK, dilution 1:70) and PgR (clone 1A6, Leica, dilution 1:70) expression, as well as TUBB3 (clone SDL3D10, BioGenex, San Ramon, CA, USA, dilution 1:1250), MAPT (clone T1029, United States Biological, Swampscott, MA, USA, dilution 1:150), HER2 (code Nu. A0485, Dako, Glostrup, DK, dilution 1:200), and ERCC1 [Excision Repair CrossComplementation group 1 protein (clone 8F1, Thermo, Fremont, CA, USA, dilution 1:450) were processed at the Laboratory of Molecular Oncology of the Hellenic Foundation for Cancer Research, Aristotle University of Thessaloniki School of Medicine and evaluated immunohistochemically at the Pathology department of the Ioannina University Hospital by AB and SK. Immunohistochemical staining was performed according to standard protocols, with slight modifications, on serial 2.5 $\mu \mathrm{m}$ thick sections from 17 Tissue Microarray (TMA) blocks, constructed with the use of a manual arrayer (Model I, Beecher Instruments, Sun Prairie, WI, USA), using 2 cores per case of $1.5 \mathrm{~mm}$ in diameter. All slides of the study for each antibody were stained in one run. Tumour samples were categorised as ER- or PgR-positive if at least $1 \%$ of malignant cells showed nuclear staining for the ER or PgR proteins, respectively [10]. Immunohistochemical (IHC) categorisation of tumour cells as HER2+ was done in the presence of $3+$ IHC expression in $>30 \%$ of tumor cells according to proposed criteria or, in the case of $2+I H C$, in the presence of gene amplification by Chromogenic In Situ Hybridisation (CISH)[11]. Immunohistochemical staining for TUBB3 and MAPT was homogeneous throughout the TMA sections and was evaluated using a semiquantitative method. In particular, the staining was cytoplasmic and was considered positive if it was of moderate or strong intensity (2+ and $3+$ respectively), as previously described by Pusztai et al[12]. Cases with absent $(0+)$ or weak $(1+)$ immunostaining were considered negative. The above mentioned criteria were also used for the analysis of the ERCC1 protein. Moderate or strong nuclear staining intensity was considered as positive, whereas cases with absent or mild immunoexpression were classified as negative. 


\section{Statistical Methodology}

Exploratory analysis was conducted in order to find a prognostic cut-off among the distribution quartiles of TUBB3 mRNA values. The median was chosen as the optimal cut-off in the prognosis of both overall survival (OS) and disease free survival (DFS). The distribution of the mRNA values of TUBB3 is shown in Figure 1. The median for MAPT and the $25^{\text {th }}$ percentile for ER and PgR were used to separate mRNA expression as previously described[13]. Considering mRNA expression of HER2, the $75^{\text {th }}$ percentile (a value close to the natural cut-off of the bimodal distribution) was a predefined threshold to separate low and high expressed tumors.

OS was measured from the date of randomisation until death from any cause. Surviving patients were censored at the date of last contact. DFS was measured from the date of randomisation until recurrence of tumour or secondary neoplasm or death from any cause. Time-to-event distributions were estimated using KaplanMeier curves[14]. The non-parametric Mann-Whitney test was performed for comparing continuous variables between two independent groups. To measure the association between the clinicopathological variables and the expression of studied biomolecules, the Fisher's exact test was implemented. Correlations among all genes under study were assessed using the Spearman correlation coefficient (Rho). The degree of agreement corrected by chance was estimated using the Kappa coefficient. Univariate Cox regression analyses, adjusted for group, were performed to assess the relationship of markers with OS or DFS. A multivariate Cox regression analysis, including age ( $<50$ vs. $\geq 50$ years), group of randomisation (E-T-CMF vs. E$\mathrm{CMF}$ ), menopausal status (pre vs. post), involved axillary lymph nodes (0-3 vs. $\geq 4$ ), histological grade (I-II vs. III-Undifferentiated), size ( $\leq 2 \mathrm{~cm}$ vs. $2-5 \mathrm{~cm}$ vs. $>5 \mathrm{~cm}$ ), mRNA expression (low vs. high) of ER, PgR, HER2, TUBB3, MAPT and ERCC1 protein expression (negative vs. positive) was conducted. A backward selection procedure with a removal criterion of $\mathrm{P}>0.10$ was applied and final tests were conducted the $\alpha=0.05$ level of significance. Results of this study are reported following the corresponding recommendations for tumour marker prognostic studies [15]. The statistical analysis was conducted using SPSS (SPSS for Windows, version 15.0, SPSS Inc.). 


\section{Results}

\section{Patient and Tumour Characteristics}

Three hundred and fourteen patients (median age 50) harboured breast carcinomas, most commonly hormone-receptor positive by IHC (68.8\% of patients), T2-3 (69.4\%) of moderate to poor differentiation (49.7\%), from which neoplastic FFPE material underwent molecular analysis for gene expression of TUBB3, ER, PgR, HER2, and MAPT (Figure 1). After modified radical mastectomy (79\%) or breast conserving surgery (21\%) and nodal dissection, neoplastic metastases in axillary lymph nodes were present in all but six cases, with four or more involved nodes in $75.5 \%$ of patients. Slightly more patients were managed with adjuvant E-CMF chemotherapy $(\mathrm{N}=170)$ than $\mathrm{E}-\mathrm{T}-\mathrm{CMF}(\mathrm{N}=144)$. With the exception of high-grade and HER2 IHC protein overexpression, which were more common in the E-T-CMF arm, basic clinicopathological characteristics were well balanced when the 314 analysed patients were stratified by adjuvant chemotherapy arm (Tables 1 and 2). Following completion of adjuvant chemotherapy, $91.7 \%$ of the 314 women received some form of hormonal therapy, mostly tamoxifen $(87.2 \%$ of patients receiving hormonotherapy). Among women with IHC ER-negative tumours who took tamoxifen, a proportion had PgR-unknown or PgR-positive tumours, while some received hormonal therapy despite having both ER and PgR-negative tumours, a practice that has since been abandoned in all HeCOG participating centres.

The profile of protein expression and gene transcription of studied biomolecules is summarized in Table 2. Among 314 tumours, 64\% expressed ER protein, 57\% PgR and $17.2 \%$ overexpressed HER2. The majority of tumours (71\%) expressed ERCC1 protein, while 40\% expressed MAPT. Only $36.3 \%$ of breast carcinomas stained moderately to strongly for cytoplasmic TUBB3, the definition used for positive cases (Figure 3a and 3b). Regarding RT-PCR studies, gene transcription defined as mRNA levels higher than the defined cut offs were seen in 
$75 \%$ of tumours for ER and PgR genes, in $25 \%$ for HER2 and in $50 \%$ of cases for the MAPT and TUBB3 genes. The distribution of TUBB3 mRNA values is shown in Figure 2. There were no significant differences in protein expression or gene transcription of studied biomolecules between treatment arms, with the exception of HER2 protein overexpression, which was seen in $22.2 \%$ of tumours in the E-T-CMF arm versus $12.9 \%$ in the $E-C M F$ arm $(p=0.045)$.

\section{Correlation of molecular and clinicopathological parameters}

The correlations of TUBB3 mRNA status (high or low) as well as of TUBB3 protein expression with standard clinicopathological and molecular factors are shown in Table 3. In general, high TUBB3 mRNA transcription was significantly associated with tumour characteristics with adverse prognostic impact, such as advanced T stage, high grade, hormone receptor protein and mRNA negativity, HER2 protein and mRNA positivity, and MAPT protein and mRNA negativity. Specifically, tumours larger than $5 \mathrm{~cm}$ were seen in $21 \%$ of TUBB3 mRNA-high versus $12.7 \%$ of TUBB3 mRNA-low cases, while high grade was documented in $56 \%$ versus $43 \%$ of TUBB3 mRNA high versus low tumours, respectively. Absence of ER and PgR protein expression was seen in $35 \%$ and $44.4 \%$ of TUBB3 mRNA-high tumours versus only $15.6 \%$ and $22.2 \%$ respectively of TUBB3 mRNA-low tumours. HER2 protein overexpression was observed in $32.8 \%$ of TUBB3 mRNA-high versus only $9.4 \%$ of TUBB3 mRNA-low breast carcinomas, while absence of MAPT protein expression was documented in $60 \%$ of TUBB3 mRNA-high versus $46 \%$ of TUBB3 mRNA-low cases. These associations were also observed with robust statistical significance between TUBB3 mRNA expression and mRNA expression status of ER, PgR, HER2, and MAPT genes. TUBB3 mRNA status was correlated to all mRNA markers at $p<0.001$ significance: negatively with ESR1 mRNA (Rho -0.333), PgR mRNA (Rho -0.291) and MAPT mRNA (Rho -0.250) and positively with ERBB2 mRNA (Rho 0.230).

In contrast, the association of TUBB3 protein expression with adverse clinicopathological variables was less common and considerably weaker. It correlated with HER2 protein overexpression, ERCC1 protein expression and low 
mRNA status of ER and PgR, as well as high mRNA status of HER2 at $p$ values ranging from 0.01 to 0.047 .

Although positive TUBB3 protein expression was associated with higher levels of TUBB3 mRNA (Mann Whitney, $p<0.001$, Figure 4), there was only poor agreement between mRNA and protein expression status (Kappa statistic 24.6\%, $p<0.001$ ) (Table 4). In fact, among tumours with higher than median TUBB3 mRNA transcription as many as $45.9 \%$ exhibited absent or weak $(0+/ 1+)$ protein staining. Conversely, among tumours with lower than median TUBB3 mRNA levels, $29.5 \%$ had moderate to strong $(2+/ 3+)$ protein expression. Using the protein expression as reference, overall agreement between the two methods was $62.4 \%$, while positive and negative agreement were $64.0 \%$ and $61.2 \%$ respectively.

\section{Outcome and Prognostic/Predictive factors}

Survival status of the 314 patients was updated in October 2007. At the time of the analysis (July 2010), the median follow up time was 98 months. During this time, 110 patients (35\%) had developed a relapse and 80 patients $(25.5 \%)$ had died. The median disease-free survival (DFS) was 121 months (95\% Cl: 105-138, 5-year DFS $71 \%$ ), while the median overall survival (OS) had not been reached yet (5-year OS $84 \%)$.

Malignant relapses occurred in $43.9 \%$ and deaths in $30.6 \%$ of the TUBB3mRNA high cases versus $26.1 \%$ relapsed and $20.4 \%$ dead patients with TUBB3-mRNA low tumours. Univariate Cox regression analysis, adjusted for treatment, showed an increased risk of death in patients with TUBB3-mRNA high tumours [hazard ratio $(H R)=1.60,95 \% \mathrm{Cl}: 1.02-2.51$, Wald $-p=0.039]$, as well as an increased risk of malignant relapse ( $\mathrm{HR}=1.84,95 \% \mathrm{Cl}: 1.26-2.68$, Wald- $\mathrm{p}=0.002)$, in comparison to those affected by TUBB3-mRNA low breast carcinomas.

In contrast, neoplastic TUBB3 protein expression did not achieve prognostic significance. Malignant relapses occurred in $28.5 \%$ and deaths in $27.2 \%$ of the TUBB3-IHC positive cases versus $33.7 \%$ relapsed and $24.3 \%$ dead patients with 
TUBB3-IHC negative tumours. Univariate Cox regression analysis, adjusted for treatment, failed to establish distinct risk of death in patients with TUBB3-IHC high tumours (HR=1.17, 95\% $\mathrm{Cl}$ : $0.73-1.87$, Wald- $p=0.52)$, or risk of relapse $(H R=1.13$, 95\% Cl: $0.76-1.67$, Wald-p=0.56), in comparison to those affected by TUBB3-IHC low breast carcinomas.

Kaplan-Meier survival curves representing the probability of survival and disease-free survival as a function of TUBB3 mRNA status are presented in Figure 5 (log-rank test for DFS $p=0.001$, for OS $p=0.04$ ). The randomisation of patients to a taxane-free versus a taxane-containing chemotherapy regimen enabled us to screen whether TUBB3 gene transcription carried a prognostic (irrespective of treatment) or predictive (identifying response to therapy) utility. However, neither TUBB3 mRNA nor IHC protein expression status were predictive for benefit from adjuvant treatment with paclitaxel (E-T-CMF arm) for either disease-free survival or overall survival (DFS and OS tests for interaction, Wald- $p=0.46$ and $p=0.96$ for TUBB3 mRNA, $p=0.95$ and $p=0.75$ for TUBB3 IHC, respectively). Since data on TUBB3 mRNA levels are continuous, we examined whether increasing tumour mRNA levels had a trend for increasing patient benefit from taxane-containing adjuvant chemotherapy. There was no interaction between mRNA levels of TUBB3 and treatment arm ( $p=0.27$ for OS and $p=0.15$ for DFS). By restricting analysis to patients who received taxanes (E-TCMF), we observed that increasing transcription of the TUBB3 gene (increasing mRNA levels as a continuous variable) remained non-predictive for benefit from adjuvant treatment with paclitaxel (DFS HR=1.11 and OS HR=1.14, Wald $-p=0.14$ and $\mathrm{p}=0.15$, respectively).

The impact of paclitaxel on OS and DFS in TUBB3 mRNA-low and high patients are shown in Figures $6 a$ and $6 \mathrm{~b}$, respectively. Since in the clinical paper, a survival benefit from the addition of paclitaxel was observed in patients harbouring ER IHCnegative tumours and ER status was inversely correlated to TUBB3 gene transcription, we investigated whether TUBB3 gene transcription was able to identify the subgroup of patients with ER IHC negative tumours who might benefit from taxanes. This analysis among ER IHC-negative patients is presented in Figures 7a and 
7b, respectively and did not show any impact of paclitaxel on either DFS or OS (logrank, $p>0.05$ in all cases ).

In keeping with data published by our group on MAPT mRNA levels, IHC MAPT expression exhibited a trend for statistical significance as a favourable prognostic factor for OS (HR=0.63, 95\% Cl: 0.39-1.02, Wald-p=0.065) and DFS (HR= $0.66,95 \% \mathrm{Cl}: 0.44-1.00$, Wald- $\mathrm{p}=0.05)$. Although, there was a non-significant trend for the interaction of MAPT protein expression and treatment group ( $p=0.08$ for both OS and DFS), there was a favourable prognostic significance for MAPT IHC protein staining when restricting in patients treated in the E-CMF arm (HR for OS=0.42 with Wald $-p=0.014$ and HR for DFS=0.45 with Wald $-p=0.009$ ).

\section{Multivariate analysis for independent prognosticators}

Multivariate Cox regression analysis (Table 5), including age, menopausal status, tumour grade, size, number of positive lymph nodes, treatment group, TUBB3, ER, PgR, HER2, and MAPT mRNA expression levels and ERCC1 protein expression revealed that only TUBB3 mRNA, PgR mRNA and number of involved axillary nodes remained significant independent predictors of OS, while TUBB3 mRNA, number of positive nodes and tumour grade independently predicted DFS. More specifically, high TUBB3 mRNA was associated with an increased risk of death $(H R=1.71,95 \% \mathrm{Cl}: 1.03-2.83, W a l d-p=0.038)$ and increased risk of relapse $(H R=1.83$, 95\% Cl: 1.25-2.68, Wald-p=0.002). As expected, four or more positive nodes were associated with an increased risk of death $(\mathrm{HR}=2.62,95 \% \mathrm{Cl}: 1.27-5.38$, Wald$\mathrm{p}=0.009)$ and relapse $(\mathrm{HR}=2.88,95 \% \mathrm{Cl}: 1.66-4.99$, Wald-p<0.001). Low PgR mRNA transcription also significantly correlated with increased risk of death (HR=0.49, 95\% $\mathrm{Cl}$ : 0.29-0.84, Wald-p=0.009). High histological grade significantly correlated with increased risk of relapse $(H R=1.68,95 \% \mathrm{Cl}: 0.82-1.71$, Wald- $p=0.007)$. Of note, factors such as treatment arm $(E-C M F H R=1.57$, Wald $-\mathrm{p}=0.065)$ and positive ERCC1 protein expression $(H R=1.93$, Wald $-p=0.087)$ exhibited a trend for adverse prognostic significance in the multivariate model for overall survival. 


\section{Discussion}

$\alpha$ - and $\beta$-tubulins are each encoded by a 9- to 8 -member multigene family, respectively that produces conserved gene products in which the sequences are divergent only in their last carboxy-terminal 10-15 aminoacids. This carboxy-terminal sequence has been used to define $\beta$-tubulin gene products to seven distinct classes or isotypes[16-18]. Class I and II $\beta$-tubulins are the most abundant isotypes, whereas the class III $\beta$-tubulin (TUBB3) was initially thought to be restricted to neuronal and testicular tissues. The TUBB3 gene is situated at chromosome 16 at the genome locus 16q24.3. Recently, however, TUBB3 expression has been observed in the mitochondria and cytoplasm of other tissues[19]. In vitro experiments and retrospective in vivo data implicated TUBB3 as a clinical marker of drug resistance to taxanes and vinca alkaloids[6]. These drugs respectively stabilise and depolymerise microtubules at high concentrations, though at concentrations 10-100 times lower, such as the ones achieved in the clinical setting, they kinetically disrupt microtubule dynamics without altering microtubule polymer mass[20]. This results in blocking transition from metaphase to anaphase and inducing apoptotic cell death. High levels of TUBB3 were associated with taxane resistance in lung, ovarian, breast, and pancreatic cancer cell lines. TUBB3 has been hypothesized to alter drug binding to tubulin dimers and to reduce the polymerisation rate of microtubules, thus overcoming polymerisation induced by taxanes, or to create a $\beta$ III microtubule dimers with different intrinsic dynamic properties that render them less sensitive to antitubulin agents[21, 22]. Molecular modelling experiments showed that Ser277, the aminoacid in the M-loop of microtubules that interacts with taxanes, is replaced by an arginine residue in the class III $\beta$-tubulin that does not bind the drug and consequently, does not result in stabilisation of lateral microtubules[23]. Several retrospective clinical series of rather small size confirmed the cell line data and correlated protein or mRNA expression of TUBB3 to resistance to taxanes[24]. Still, these series could not discern the prognostic (patient outcome irrespective of therapy) versus predictive (probability of benefit from taxane-based therapy) significance of this biomolecule. 
Our retrospective analysis of 314 patients with high-risk resected breast cancer used quantitative mRNA transcription levels of TUBB3. We showed for the first time in the adjuvant setting that TUBB3 RNA expression in breast cancer tissues is significantly correlated to adverse clinicopathological characteristics (advanced T stage, anaplasia, hormone receptor negativity, HER2 overexpression) and inferior patient outcome. Moreover, multivariate analysis revealed that high TUBB3 mRNA transcription retained independent prognostic significance for both OS and DFS. Finally, the randomisation of patients to a taxane-containing and a taxane-free chemotherapy arm enabled us to show that TUBB3 gene transcription is prognostic for adverse outcome but not predictive for resistance to taxanes. Taking into consideration the high $p$ values for interaction of TUBB3 status with treatment arm and the moderately large sample size, we can rather confidently rule out a clinically significant predictive utility of TUBB3 for taxane efficacy.

Evidence from other investigators seem to confirm our findings and refute the taxane-resistant phenotype hypothesis for TUBB3. In the JBR.10 trial, 482 patients with resected non small cell lung cancer were randomised to observation versus adjuvant cisplatin/vinorelbine chemotherapy[25]. In 265 patients examined, immunohistochemical TUBB3 protein expression was prognostic for poorer recurrence-free and overall survival in the observation, but not in the chemotherapy arm. Cox regression analysis failed to establish a significant interaction between TUBB3 IHC expression and chemotherapy in predicting outcome. Very recently, Dumontet et al analysed 1350 patients with resected node-positive breast cancer who had been randomised to TAC (docetaxel, adriamycin, cyclophosphamide) versus FAC adjuvant chemotherapy by studying the immunohistochemical protein expression of several biomolecules[26]. In multivariate analysis, high TUBB3 protein expression was significantly associated with poorer OS but lacked predictive utility for docetaxel efficacy, as the correlation with outcome was observed in both TAC and FAC arms and interaction testing revealed no differences within treatment subgroups. In our study, we failed to show any TUBB3 predictive significance for taxane benefit even when we restricted our analysis to two patient subgroups: 1) In those patients who received the taxane-containing therapy (E-T-CMF), there was no 
association of increasing TUBB3 mRNA levels with outcome, rather convincingly establishing the lack of a dose-response relation between gene transcription and taxane effect. 2) Since in the HE10/97 trial a benefit from taxane was seen only in patients with ER IHC-negative tumours, we analysed and failed to find any predictive significance of TUBB3 mRNA status for taxane efficacy in the ER IHC-negative subroup.

The adverse prognostic, but not predictive significance of TUBB3 mRNA may not seem paradoxical in view of emerging in vitro data: the TUBB3 gene is located at $16 q 24.3$ and contains a promoter region, an enhancer sequence and an E-box binding site for transcription factors that all drive its transcription. Hypoxiadependent transcription factors, such as Stimulating Protein-1, Wilms tumour suppressor, p53, and NFkB induce gene expression, in keeping with the observation that TUBB3 is more expressed in hypoxic tumours (breast, ovarian cancer) than in normal mammary and ovarian biopsies[27,28]. Gan et al have recently shown that TUBB3 is overexpressed not only in taxane-resistant but also in cisplatin-refractory cancer cell lines[29]. TUBB3 indeed interacts with a plethora of cellular proteins, such as HSP70, FMO4 and Pyruvate Kinase M1. A functional analysis of the network of proteins associated to TUBB3 shows that many of them are involved in oxidative stress, glucose deprivation response and cell cycle control[19]. Accordingly, TUBB3 seems to be integrated in a survival pathway, which is initiated by hypoxia and effects adaptation of cancer cells to a microenvironment with low oxygen and poor nutrient supply. Increased TUBB3 gene trancription could therefore be a marker of aberrant activation of this «hypoxia lethal phenotype», resulting in cancer proliferation, metastatic dissemination and poor patient outcome. . In addition to increased transcription, other mechanisms such as TUBB3 gene amplification, epigenetic regulation or decreased expression of repressing RNAs, such as microRNAs, might contribute to relatively high TUBB3 mRNA expression. Amplification of the TUBB3 gene seems, in fact, unlikely and has not been reported in breast cancer; the chromosomal region 16q24.3, as well as genes located centromerically or telomerically to TUBB3 have repeatedly been reported as deleted in breast cancer[30-32]. In regard to the latter two options, TUBB3 gene 
transcription seems to be induced by hypoxia in cisplatin-sensitive ovarian cancer cells lacking methylation in the 3 '-enhancer region of this gene, while the miR-200 family that, among other targets, represses TUBB3 mRNA is downregulated in human cancer cells (Mongroo and Rustgi 2010)[28,33]. Whether these mechanisms apply to breast cancer tissues warrants further investigation.

The correlation of TUBB3 mRNA levels with protein expression was poor in our study, with a Kappa statistic of only 0.24. Moreover, in contrast to protein, mRNA expression was associated strongly with adverse clinicopathological factors and retained independent prognostic significance for outcome. Among hypotheses that could interpret the finding, we could cite mRNA failing to translate to protein (alternate splicing, aberrant polyadenylation, microRNA-mediated or other form of translational silencing), protein degradation in the tumour block by inadequate fixation, problematic antigen retrieval, protein staining underestimation in old archival material, or finally, RNA amplification of normal tissue along with the tumour[34-36]. Conversely, protein staining in the face of low level gene transcription could be due to the difficulty in capturing short-lived, sensitive to degradation mRNA from FFPE tumour blocks, the different fixation and turnover times of ribonucleic acids in relation to proteins, as well as accumulation of protein due to aberrant catabolism[37, 38]. In any case, TUBB3 mRNA as a continuous, objectively measured variable, was shown to possess correlative and prognostic characteristics not present when evaluating expression of the corresponding protein.

In a report previously published by our group we showed that high-level Tau gene (MAPT) transcription has prognostic significance for favourable patient outcome, though no predictive utility for taxane benefit[13]. Our findings were confirmed by the demonstration of prognostic, but not predictive utility for Tau protein expression among breast cancer patients receiving taxane-based adjuvant chemotherapy in the NSABP-B28 $(n=1942)$ and the BCIRG001 $(n=1350)$ randomised trials[26,38]. Still other investigators have reported association between low MAPT mRNA or IHC levels with response to taxanes and resistance to tamoxifen[40,41]. In our previous report we speculated that, since all patients who had received adjuvant taxane therapy were also managed with hormonotherapy, in those with low MAPT 
mRNA levels the positive predictive significance for taxane benefit could have been "cancelled» by the predictive utility for tamoxifen resistance. In this study, MAPT protein expression had strong favourable prognostic significance only in patients receiving $\mathrm{E}-\mathrm{CMF}$, but not in those receiving a taxane. It is tempting to speculate that in the E-T-CMF patients, the favourable prognosis afforded by MAPT protein overexpression was diluted by the lack of taxane efficacy. This observation could serve as additional preliminary evidence that high MAPT gene or protein expression serve as both markers of favourable prognosis and markers of resistance to taxanes.

To conclude, our work has established a prognostic significance of the transcription of two gene products related to microtubules, $\beta$-tubulin isotype III and MAPT. These biomolecules could serve as useful prognosticators and stratification factors in future trials. Still, their function and relation to other biomolecules should be further investigated, while their prognostic and potentially predictive value remains to be validated. HeCOG plans to validate these findings in over 900 breast cancer blocks from a subsequent adjuvant chemotherapy study (He 10/00). 


\section{Acknowledgements}

The authors wish to thank Ms. Evita Fragou and Ms. Dimitra Katsala for monitoring the study, Ms. Maria Moschoni for coordinating the data management and Ms. Thalia Spinari for tissue sample collection. . On behalf of the Hellenic Foundation for Cancer Research, Athens, Greece, the senior author (GF) has pending patent applications with Siemens Healthcare Diagnostics, Cologne, Germany.

\section{References}

1. EBCTC Group. Effects of chemotherapy and hormonal therapy for early breast cancer on recurrence and 15-year survival:an overview of the randomised trials. Lancet 2005;365:1687-1717

2. Trudeau M, Charbonneau F, Gelmon K et al. Selection of adjuvant chemotherapy for treatment of node-positive breast cancer. Lancet Oncol 2005;6:886-898

3. Philippe L. Bedard, Angelo Di Leo and Martine J. Piccart-Gebhart. Taxanes: optimizing adjuvant chemotherapy for early-stage breast cancer. Nat. Rev. Clin. Oncol. 2010;7:22-36

4. Bhat KMR, Setaluri V. Microtubule-associated proteins as targets in cancer chemotherapy. Clin Cancer Res 2007;13:2849-2854

5. Mollinedo, F. \& Gajate, C. Microtubules, microtubule-interfering agents and apoptosis. Apoptosis 2003; 8:413-450

6. Kavallaris M. Microtubules and resistance to tubulin-binding agents. Nat Rev Cancer 2010;10:194-204

7. Fountzilas G, Skarlos D, Dafni U, Gogas H, Briasoulis E et al. Postoperative dose-dense sequential chemotherapy with epirubicin, followed byCMFwith or without paclitaxel, in patients with high-risk operable breast cancer: a randomised phase III study conducted by the Hellenic Cooperative Oncology Group. Ann Oncol 2005;16:1762-1771

8. Bohmann K, Hennig G, Rogel U, Poremba C, Mueller BM, Fritz P, Stoerkel S, Schaefer K-L. RNA extraction from archival formalin-fixed paraffin-embedded tissue: a comparison of manual, semiautomated, and fully automated purification methods. Clin Chem 2009;55:1719-1727

9. Mueller BM, Kronenwett R, Hennig G, Euting H, Weber K, et al. Quantitative determination of estrogen receptor, progesterone receptor and HER2 mRNA in formalinfixed paraffin-embedded tissue-a new option for predictive biomarker assessment in breast cancer. Diagn Mol Pathol 2011;20:1-10

10. Hammond ME, Hayes DF, Dowsett M, Allred DC, Hagerty KL, Badve S, et al. American Society of Clinical Oncology/College Of American Pathologists guideline recommendations for immunohistochemical testing of estrogen and progesterone receptors in breast cancer. J Clin Oncol. 2010;28:2784-95 
11. Wolff AC, Hammond ME, Schwartz JN, Hagerty KL, Allred DC, Cote RJ, et al. American Society of Clinical Oncology/College of American Pathologists guideline recommendations for human epidermal growth factor receptor 2 testing in breast cancer. Arch Pathol Lab Med. 2007;131:18-43

12. Lajos Pusztai, Jong-Hyeon Jeong, Yun Gong, Jeffrey S. Ross, Chungyeul Kim, Soonmyung Paik, et al. Evaluation of Microtubule-Associated Protein-Tau Expression As a Prognostic and Predictive Marker in the NSABP-B 28 Randomized Clinical Trial. J Clin Oncol 2009;27:42874292

13. George Pentheroudakis, Konstantine T. Kalogeras, Ralph M. Wirtz, Irene Grimani, George Zografos, Helen Gogas, et al. Gene expression of estrogen receptor, progesterone receptor and microtubule-associated protein Tau in high-risk early breast cancer: a quest for molecular predictors of treatment benefit in the context of a Hellenic Cooperative Oncology Group trial. Breast Cancer Res Treat 2009;116:131-143

14. . Hudis TL. Proposal for standardized definitions for efficacy end points in adjuvant breast cancer trials: the STEEP system. J Clin Oncol 2007;25:2127-2132

15. McShane LM, Altman DG, Sauerbrei W et al (2005) Reporting recommendations for tumor marker prognostic studies. J Clin Oncol 23:9067-9072

16. Jordan MA, Wilson L. Microtubules as a target for anticancer drugs. Nat Rev Cancer 2004;4:253-65.

17. Cleveland DW, Sullivan KF. Molecular biology and genetics of tubulin. Annu Rev Biochem 1985;54:331-65.

18. Lopata MA, Cleveland DW. In vivo microtubules are copolymers of available $h$-tubulin isotypes: localization of each of six vertebrate h-tubulin isotypes using polyclonal antibodies elicited by synthetic peptide antigens. J Cell Biol 1987;105:1707-20.

19. Cicchillitti L, Penci R, Di Michele M, Fillipetti F, Rotilio D, Benedetta Donati M, et al. Proteomic characterisation of cytoskeletal and mitochondrial class III b-tubulin. Mol Cancer Ther 2008;7:2070-79

20. Orr GA, Verdier-Pinard P, McDaid H, Horwitz SB. Mechanisms of taxol resistance related to microtubules. Oncogene 2003;22:7280-95

21. Mozzetti S, Ferlini C, Concolino P, Fillippetti F, Raspaglio G, Prislei S, et al. Class III btubulin overexpression is a prominent mechanism of paclitaxel resistance in ovarian cancer patients. Clin Cancer Res 2005;11:298-305

22. Hasegawa S, Miyoshi Y, Egawa C, et al. Prediction of response to docetaxel by quantitative analysis of class I and III beta-tubulin isotype mRNA expression in human breast cancers. Clin Cancer Res 2003;9:2992-7

23. Magnani M, Ortuso F, Soro S, Alcaro S, Tramontano A, Botta M. The beta/beta III tubulin isoforms and their complexes with antimitotic agents: Docking and molecular dynamics studies. FEBS J 2006;273:3301-10

24. Seve $P$, Dumontet $C$. Is class III b-tubulin a predictive factor in patients receiving tubulinbinding agents? Oncology 2008;9:168-75

25. Seve $P$, Lai R, Ding K, et al. Class III beta tubulin expression and benefit from adjuvant cisplatin/vinorelbine chemotherapy in operable non-small cell lung cancer. Analysis of $\mathrm{NCIC}$ BR.10. Clin Cancer Res 2007;13:994-99 
26. Dumontet C, Krajewska M, Treilleux I, Mackey JR, Martin M, Rupin M, et al. BCIRG 001 molecular analysis: prognostic factors in node-positive breast cancer patients receiving adjuvant chemotherapy. Clin Cancer Res. 2010;16:3988-97.

27. Dennis K, Ulttenbogaard M, Chiaramello A, Moody SA. Cloning and characterisation of 5flanking region of the rat neuron-specific class III beta-tubulin gene. Gene 2002;294:269-77

28. Raspaglio G, Filipetti F, Prislei S, et al. Hypoxia induces Class III beta-tubulin gene expression by HIF1a binding to its 3-flanking region. Gene 2008;409:100-8

29. Gan PP, Pasquier E, Kavallaris M. Class III b-tubulin mediates sensitivity to chemotherapeutic drugs in non small cell lung cancer. Cancer Res 2007;67:9356-63.

30. Loo LW, Grove DI, Williams EM, Neal CL, Cousens LA, et al. Array comparative genomic hybridization analysis of genomic alterations in breast cancer subtypes. Cancer Res. 2004 Dec 1;64(23):8541-9.

31. Kaur GP, Reddy DE, Zimonjic DB, de Riel JK, Athwal RS. Functional identification of a BAC clone from 16q24 carrying a senescence gene SEN16 for breast cancer cells. Oncogene. 2005 Jan $6 ; 24(1): 47-54$.

32. Chin SF, Wang Y, Thorne NP, Teschendorff AE, Pinder SE, Vias M, et al. Using arraycomparative genomic hybridization to define molecular portraits of primary breast cancers. Oncogene. 2007 Mar 22;26(13):1959-70.

33. Mongroo PS, Rustgi AK. The role of the miR-200 family in epithelial-mesenchymal transition. Cancer Biol Ther. 2010 Aug;10(3):219-22

34. Goldstein NS, Ferkowicz M, Odish E et al (2003) Minimum formalin fixation time for consistent estrogen receptor immunocytochemical staining of invasive breast carcinoma. Am J Clin Pathol 120:86-92

35. Rhodes A (2003) Quality assurance in immunohistochemistry. Am J Surg Pathol 27:12841285

36. Morris KV (2008) RNA-mediated transcriptional gene silencing in human cells. Curr Top Microbiol Immunol 320:211-224

37. Ravo M, Mutarelli M, Ferraro L, Grober OM, Paris O et al (2008) Quantitative expression profiling of highly degraded RNA from formalin-fixed paraffin-embedded breast tumour biopsies by oligonucleotide microarrays. Lab Invest 88:430-440

38. Yasuda J, Hayashizaki Y (2008) The RNA continent. Adv Cancer Res 99:77-112

39. Pusztai L, Jeong JH, Gong Y, Ross JS, Chungyeul K, Soonmyung P, et al. Evaluation of Microtubule-associated protein Tau expression as a prognostic and predictive marker in the NSABP-B28 randomised clinical trial. J Clin Oncol 2009;27:4287-92.

40. Rouzier R, Rajan R, Wagner P, Hess KR, Gold DL et al (2005) Microtubule-associated protein tau: a marker of paclitaxel sensitivity in breast cancer. PNAS 102:8315-8320

41. Andre F, Hatzis C, Anderson K, Sotiriou S, Mazouni C et al (2007) Microtubule-associated protein tau is a bifunctional predictor of endocrine sensitivity and chemotherapy resistance in estrogen-receptor positive breast cancer. Clin Cancer Res 13:2061-2067 


\section{Appendix 1.}

Primers and Probes (FAM/TAMRA-labelled) used for qRT-PCR of ER, PgR, HER2, and MAPT (5' -> $\left.3^{\prime}\right)$.

ESR1

Probe ATGCCCTTTTGCCGATGCA

Forward Primer GCCAAATTGTGTTTGATGGATTAA

Reverse Primer GACAAAACCGAGTCACATCAGTAATAG

PgR

Probe TTGATAGAAACGCTGTGAGCTCGA

Forward Primer AGCTCATCAAGGCAATTGGTTT

Reverse Primer ACAAGATCATGCAAGTTATCAAGAAGTT

HER2

Probe ACCAGGACCCACCAGAGCGGG

Forward Primer CCAGCCTTCGACAACCTCTATT

Reverse Primer TGCCGTAGGTGTCCCTTTG

MAPT

Probe AGACTATTTGCACACTGCCGCCT

Forward Primer GTGGCTCAAAGGATAATATCAAACAC

Reverse Primer ACCTTGCTCAGGTCAACTGGTT 
Table 1. Patient and Tumour Characteristics.

\begin{tabular}{|c|c|c|c|c|c|c|c|}
\hline & $\begin{array}{r}\text { E-T } \\
(\mathrm{N}=\end{array}$ & & & & p & $\begin{array}{r}\text { All p } \\
(\mathbf{N}\end{array}$ & $\begin{array}{l}\text { ients } \\
\text { 14) }\end{array}$ \\
\hline & Median & Range & Median & Range & & Median & Range \\
\hline Age (years) & 49 & $24-76$ & 50 & $22-78$ & 0.273 & 50 & $22-78$ \\
\hline & $\mathbf{N}$ & $\%$ & $\mathbf{N}$ & $\%$ & & $\mathbf{N}$ & $\%$ \\
\hline Positive nodes & & & & & 0.293 & & \\
\hline 0-3 nodes & 31 & 21.5 & 46 & 27.1 & & 77 & 24.5 \\
\hline$\geq 4$ nodes & 113 & 78.5 & 124 & 72.9 & & 237 & 75.5 \\
\hline Menopausal status & & & & & 0.999 & & \\
\hline Premenopausal & 78 & 54.2 & 92 & 54.1 & & 170 & 54.1 \\
\hline Postmenopausal & 66 & 45.8 & 78 & 45.9 & & 144 & 45.9 \\
\hline Type of operation & & & & & 0.999 & & \\
\hline Modified radical mastectomy & 114 & 79.2 & 134 & 78.8 & & 248 & 79.0 \\
\hline Breast conserving surgery & 30 & 20.8 & 36 & 21.2 & & 66 & 21.0 \\
\hline Nuclear grade* & & & & & 0.013 & & \\
\hline I-II & 61 & 42.4 & 97 & 57.1 & & 158 & 50.3 \\
\hline III-Undifferentiated & 83 & 57.6 & 73 & 42.9 & & 156 & 49.7 \\
\hline Tumour size & & & & & 0.596 & & \\
\hline$\leq 2 \mathrm{~cm}$ & 42 & 29.2 & 54 & 31.8 & & 96 & 30.6 \\
\hline $2-5 \mathrm{~cm}$ & 80 & 55.6 & 85 & 50.0 & & 165 & 52.5 \\
\hline$>5 \mathrm{~cm}$ & 22 & 15.3 & 31 & 18.2 & & 53 & 16.9 \\
\hline Adjuvant radiotherapy & & & & & 0.373 & & \\
\hline No & 22 & 15.3 & 33 & 19.4 & & 55 & 17.5 \\
\hline Yes & 121 & 84.0 & 136 & 80.0 & & 257 & 81.8 \\
\hline Missing data & 1 & 0.7 & 1 & 0.6 & & 2 & 0.6 \\
\hline Adjuvant hormonotherapy & & & & & 0.305 & & \\
\hline No & 9 & 6.3 & 17 & 10.0 & & 26 & 8.3 \\
\hline Yes & 135 & 93.8 & 153 & 90.0 & & 288 & 91.7 \\
\hline
\end{tabular}

* Distribution of grade differs significantly between the two groups $(p=0.013)$. 
Table 2. Protein expression and gene transcription of TUBB3, ER, PgR, HER2, MAPT, ERCC1 in the studied population.

\begin{tabular}{|c|c|c|c|c|c|c|c|}
\hline ER protein status (centrally) & \multicolumn{2}{|c|}{$\begin{array}{c}\text { E-T-CMF } \\
(\mathrm{N}=144)\end{array}$} & \multicolumn{2}{|c|}{$\begin{array}{l}\text { E-CMF } \\
(\mathbf{N}=170)\end{array}$} & $\frac{\mathbf{p}}{0.888}$ & \multicolumn{2}{|c|}{$\begin{array}{l}\text { All patients } \\
(\mathbf{N}=314)\end{array}$} \\
\hline Negative & 33 & 22.9 & 35 & 20.6 & & 68 & 21.7 \\
\hline Positive & 94 & 65.3 & 107 & 62.9 & & 201 & 64.0 \\
\hline Missing data & 17 & 11.8 & 28 & 16.5 & & 45 & 14.3 \\
\hline PgR protein status (centrally) & & & & & 0.999 & & \\
\hline Negative & 42 & 29.2 & 47 & 27.6 & & 89 & 28.3 \\
\hline Positive & 85 & 59.0 & 94 & 55.3 & & 179 & 57.0 \\
\hline Missing data & 17 & 11.8 & 29 & 17.1 & & 46 & 14.6 \\
\hline HER2 protein status (centrally)** & & & & & 0.045 & & \\
\hline Negative & 87 & 60.4 & 115 & 67.6 & & 202 & 64.3 \\
\hline Positive & 32 & 22.2 & 22 & 12.9 & & 54 & 17.2 \\
\hline Missing data & 25 & 17.4 & 33 & 19.4 & & 58 & 18.5 \\
\hline ERCC1 protein status (centrally) & & & & & 0.339 & & \\
\hline Negative & 19 & 13.2 & 29 & 17.1 & & 48 & 15.3 \\
\hline Positive & 108 & 75.0 & 115 & 67.6 & & 223 & 71.0 \\
\hline Missing data & 17 & 11.8 & 26 & 15.3 & & 43 & 13.7 \\
\hline TAU protein status (centrally) & & & & & 0.543 & & \\
\hline Negative & 65 & 45.1 & 77 & 45.3 & & 142 & 45.2 \\
\hline Positive & 63 & 43.8 & 64 & 37.6 & & 127 & 40.4 \\
\hline Missing data & 16 & 11.1 & 29 & 17.1 & & 45 & 14.3 \\
\hline TUBB3 protein status (centrally) & & & & & 0.625 & & \\
\hline Negative & 78 & 54.2 & 82 & 48.2 & & 160 & 51.0 \\
\hline Positive & 52 & 36.1 & 62 & 36.5 & & 114 & 36.3 \\
\hline Missing data & 14 & 9.7 & 26 & 15.3 & & 40 & 12.7 \\
\hline ER mRNA status & & & & & 0.999 & & \\
\hline Low & 36 & 25.0 & 42 & 24.7 & & 78 & 24.8 \\
\hline High & 108 & 75.0 & 128 & 75.3 & & 236 & 75.2 \\
\hline PgR mRNA status & & & & & 0.433 & & \\
\hline Low & 39 & 27.1 & 39 & 22.9 & & 78 & 24.8 \\
\hline High & 105 & 72.9 & 131 & 77.1 & & 236 & 75.2 \\
\hline HER2 mRNA status & & & & & 0.999 & & \\
\hline Low & 108 & 75.0 & 128 & 75.3 & & 236 & 75.2 \\
\hline High & 36 & 25.0 & 42 & 24.7 & & 78 & 24.8 \\
\hline MAPT mRNA status & & & & & 0.428 & & \\
\hline Low & 68 & 47.2 & 89 & 52.4 & & 157 & 50.0 \\
\hline High & 76 & 52.8 & 81 & 47.6 & & 157 & 50.0 \\
\hline
\end{tabular}

** There is a marginally significant difference in the distribution of protein expression of HER2 across the two groups $(p=0.045)$. 
Table 3. Correlations of TUBB3 gene transcription and protein expression with clinicopathologic and molecular variables.

\begin{tabular}{|c|c|c|c|c|c|c|c|}
\hline & & \multicolumn{3}{|c|}{$\begin{array}{c}\text { TUBB3 mRNA expression } \\
(\mathbf{N}=314)\end{array}$} & \multicolumn{3}{|c|}{$\begin{array}{c}\text { TUBB3 protein expression } \\
(\mathrm{N}=274)\end{array}$} \\
\hline & & $\begin{array}{l}\text { Low }(\mathbf{n}=157) \\
\quad \mathbf{N}(\%)\end{array}$ & $\begin{array}{l}\text { High }(\mathrm{n}=157) \\
\quad \mathrm{N}(\%)\end{array}$ & p-value & $\begin{array}{l}\text { Negative }(\mathrm{n}=160) \\
\mathbf{N}(\%)\end{array}$ & $\begin{array}{c}\text { Positive (n=114) } \\
\text { N }(\%)\end{array}$ & p-value \\
\hline \multirow{2}{*}{ Age } & $<50$ & $77(49.0)$ & $81(51.9)$ & \multirow{2}{*}{0.652} & $72(45.3)$ & $62(54.4)$ & \multirow{2}{*}{0.143} \\
\hline & $\geq 50$ & $80(51.0)$ & $75(48.1)$ & & 87 (54.7) & $52(45.6)$ & \\
\hline \multirow{2}{*}{ Treatment group } & E-T-CMF & $70(44.6)$ & $74(47.1)$ & \multirow{2}{*}{0.734} & $78(48.8)$ & $52(45.6)$ & \multirow{2}{*}{0.625} \\
\hline & E-CMF & $87(55.4)$ & $83(52.9)$ & & $82(51.3)$ & $62(54.4)$ & \\
\hline \multirow{2}{*}{ Menopausal status } & Premenopausal & $81(51.6)$ & $89(56.7)$ & \multirow{2}{*}{0.428} & $83(51.9)$ & $63(55.3)$ & \multirow{2}{*}{0.624} \\
\hline & Postmenopausal & $76(48.4)$ & $68(43.3)$ & & $77(48.1)$ & $51(44.7)$ & \\
\hline \multirow{2}{*}{ Positive nodes } & $0-3$ & $34(21.7)$ & $43(27.4)$ & \multirow{2}{*}{0.294} & $35(21.9)$ & $27(23.7)$ & \multirow{2}{*}{0.770} \\
\hline & $\geq 4$ & $123(78.3)$ & $114(72.6)$ & & $125(78.1)$ & $87(76.3)$ & \\
\hline \multirow{3}{*}{ Tumor size } & $\leq 2$ & $57(36.3)$ & $39(24.8)$ & \multirow{3}{*}{0.035} & $57(35.6)$ & $30(26.3)$ & \multirow{3}{*}{0.262} \\
\hline & $2-5$ & $80(51.0)$ & $85(54.1)$ & & $78(48.8)$ & $63(55.3)$ & \\
\hline & $>5$ & $20(12.7)$ & $33(21.0)$ & & $25(15.6)$ & $21(18.4)$ & \\
\hline \multirow{2}{*}{ Nuclear grade } & I-II & $89(56.7)$ & $69(43.9)$ & \multirow{2}{*}{0.032} & $89(55.6)$ & $51(44.7)$ & \multirow{2}{*}{0.086} \\
\hline & III-Undifferentiated & $68(43.3)$ & $88(56.1)$ & & 71 (44.4) & $63(55.3)$ & \\
\hline \multirow{2}{*}{ ER protein status } & Negative & $21(15.6)$ & $47(35.1)$ & \multirow{2}{*}{$<0.001$} & $32(21.3)$ & $35(31.0)$ & \multirow{2}{*}{0.087} \\
\hline & Positive & $114(84.4)$ & $87(64.9)$ & & $118(78.7)$ & $78(69.0)$ & \\
\hline \multirow{2}{*}{ PgR protein status } & Negative & $30(22.2)$ & $59(44.4)$ & \multirow{2}{*}{$<0.001$} & $48(31.6)$ & $40(36.0)$ & \multirow{2}{*}{0.509} \\
\hline & Positive & $105(77.8)$ & $74(55.6)$ & & $104(68.4)$ & $71(64.0)$ & \\
\hline \multirow{2}{*}{ HER2 protein status } & Negative & $116(90.6)$ & $86(67.2)$ & & $119(83.8)$ & $81(72.3)$ & \\
\hline & Positive & $12(9.4)$ & $42(32.8)$ & $<0.001$ & $23(16.2)$ & $31(27.7)$ & 0.031 \\
\hline & Negative & $20(14.4)$ & $28(21.2)$ & & $35(22.6)$ & $11(9.7)$ & \\
\hline ERCC1 protein status & Positive & $119(85.6)$ & $104(78.8)$ & 0.154 & $120(77.4)$ & $102(90.3)$ & 0.008 \\
\hline & Negative & $63(46.0)$ & $79(59.8)$ & & $82(54.3)$ & $59(51.8)$ & \\
\hline TAU protein status & Positive & $74(54.0)$ & $53(40.2)$ & 0.028 & $69(45.7)$ & $55(48.2)$ & 0.710 \\
\hline & No & $7(4.5)$ & $19(12.1)$ & & $15(9.4)$ & $9(7.9)$ & \\
\hline Adjuvant hormonotherapy & Yes & $150(95.5)$ & $138(87.9)$ & 0.023 & $145(90.6)$ & $105(92.1)$ & 0.829 \\
\hline & Yes & $132(84.6)$ & $125(80.1)$ & & $129(81.6)$ & $96(84.2)$ & \\
\hline ER mRNA status & Low & $18(11.5)$ & $60(38.2)$ & $<0001$ & $33(20.6)$ & $37(32.5)$ & \\
\hline & High & $139(88.5)$ & $97(61.8)$ & $<0.001$ & $127(79.4)$ & $77(67.5)$ & 0.035 \\
\hline PgR mRNA status & Low & $22(14.0)$ & $56(35.7)$ & & $31(19.4)$ & $38(33.3)$ & \\
\hline & High & $135(86.0)$ & $101(64.3)$ & $<0.001$ & $129(80.6)$ & 76 966.7) & 0.011 \\
\hline HER2 mRNA status & Low & $134(85.4)$ & $102(65.0)$ & & $128(80.0)$ & $79(69.3)$ & 0.047 \\
\hline & High & $23(14.6)$ & $55(35.0)$ & $<0.001$ & $32(20.0)$ & $35(30.7)$ & 0.047 \\
\hline MAPT mRNA status & Low & $59(37.6)$ & $98(62.4)$ & $<0001$ & $71(44.4)$ & $62(54.4)$ & 0112 \\
\hline & High & $98(62.4)$ & $59(37.6)$ & $<0.001$ & 89 (55.6) & $52(45.6)$ & 0.112 \\
\hline
\end{tabular}


Table 4. Concordance of mRNA and IHC expression of TUBB3.

\begin{tabular}{|c|c|c|c|}
\hline & \multicolumn{2}{|c|}{ Protein expression of TUBB3 } \\
\hline & & Negative & Positive \\
\hline & & $\mathrm{N}(\%)$ & $\mathrm{N}(\%)$ \\
\hline \multirow[t]{2}{*}{ TUBB3 mRNA } & Low $(<$ median $)$ & $98(61.2)$ & $41(36.0)$ \\
\hline & High $(\geq$ median $)$ & $62(38.8)$ & $73(64.0)$ \\
\hline Positive agreement & \multirow{4}{*}{\multicolumn{2}{|c|}{$\begin{array}{l}64.0 \% \\
61.2 \% \\
62.4 \% \\
24.6 \%(<0.001)\end{array}$}} & \\
\hline Negative agreement & & & \\
\hline Overall agreement & & & \\
\hline Kappa statistic (p-value) & & & \\
\hline
\end{tabular}


Table 5. Multivariate analysis for prognostic significance: Parameters in the final step.

\begin{tabular}{|c|c|c|c|c|c|c|}
\hline & & Survival & & & DFS & \\
\hline & HR & $95 \% \mathrm{CI}$ & Wald-p & HR & $95 \% \mathrm{CI}$ & Wald-p \\
\hline Randomisation gr & & & & & & \\
\hline$E-T-C M F$ & 1 & & & 1 & & \\
\hline$E-C M F$ & 1.574 & $0.972-2.549$ & 0.065 & 1.184 & $0.818-1.714$ & 0.371 \\
\hline Age & & & & & & \\
\hline$<50$ & 1 & & & & & \\
\hline$\geq 50$ & 0.659 & $0.404-1.073$ & 0.093 & & & \\
\hline Grade & & & & & & \\
\hline$I-I I$ & 1 & & & 1 & & \\
\hline III-Undif & 1.184 & $0.715-1.961$ & 0.512 & 1.679 & $0.818-1.714$ & 0.007 \\
\hline Number of positiv & & & & & & \\
\hline $0-3$ & 1 & & & 1 & & \\
\hline$\geq 4$ & 2.618 & $1.274-5.381$ & 0.009 & 2.876 & $1.659-4.986$ & $<0.001$ \\
\hline PgR mRNA status & & & & & & \\
\hline Low & 1 & & & & & \\
\hline High & 0.492 & $0.289-0.838$ & 0.009 & & & \\
\hline ERCC1 protein stat & & & & & & \\
\hline Negative & 1 & & & & & \\
\hline Positive & 1.927 & $0.908-4.091$ & 0.087 & & & \\
\hline TUBB3 mRNA sta & & & & & & \\
\hline Low & 1 & & & 1 & & \\
\hline High & 1.708 & $1.031-2.831$ & 0.038 & 1.833 & $1.252-2.685$ & 0.002 \\
\hline
\end{tabular}


Figure 1: REMARK Study flow-chart

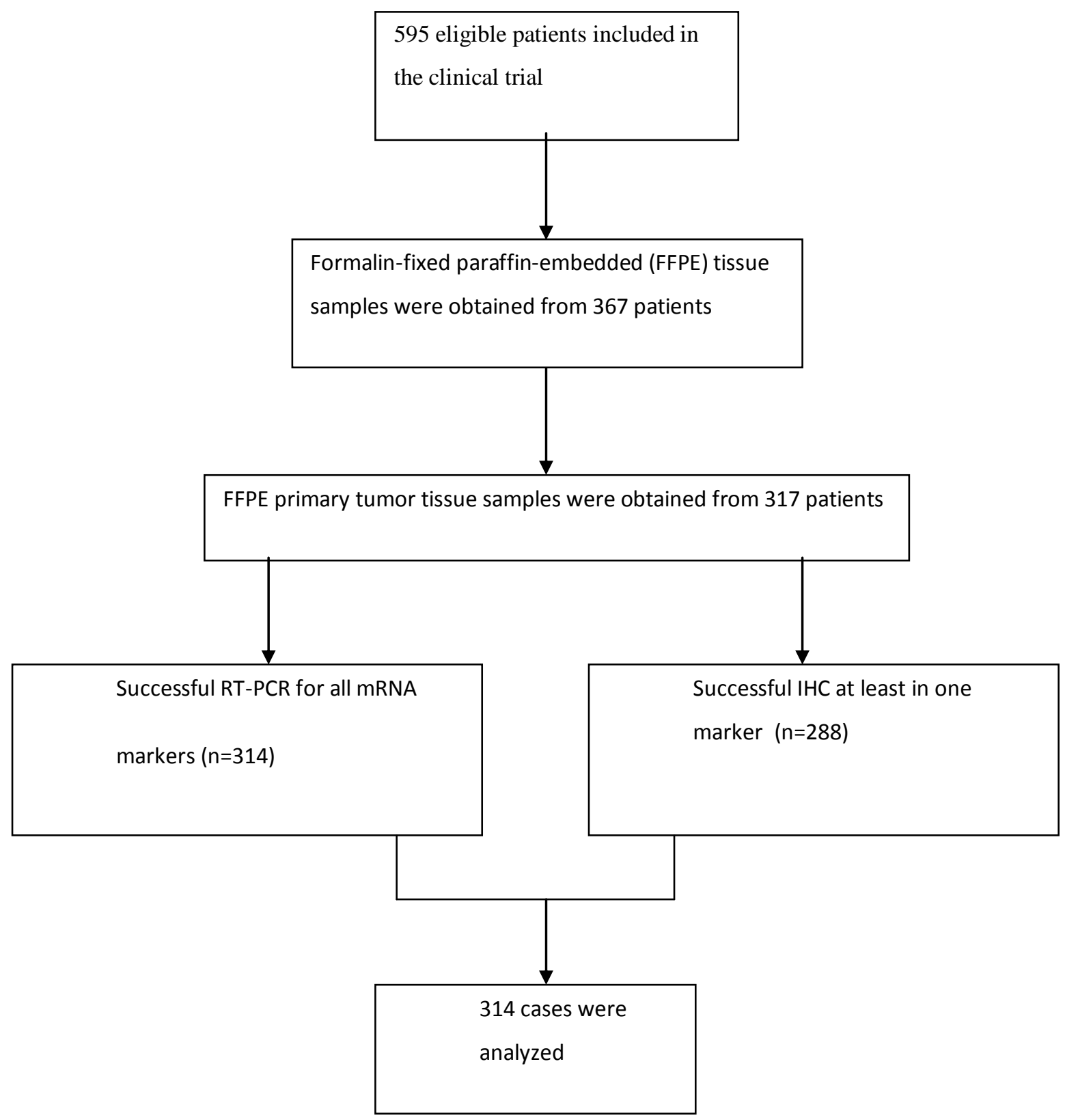


Figure 2. Distribution of tumoural TUBB3 mRNA levels in the studied population. Values in the $x$-axis represent the difference $40-\Delta C T$. Median $31.92,25^{\text {th }}$ percentile $30.43,75^{\text {th }}$ percentile 33.38, Range: $26.28-36.51$.

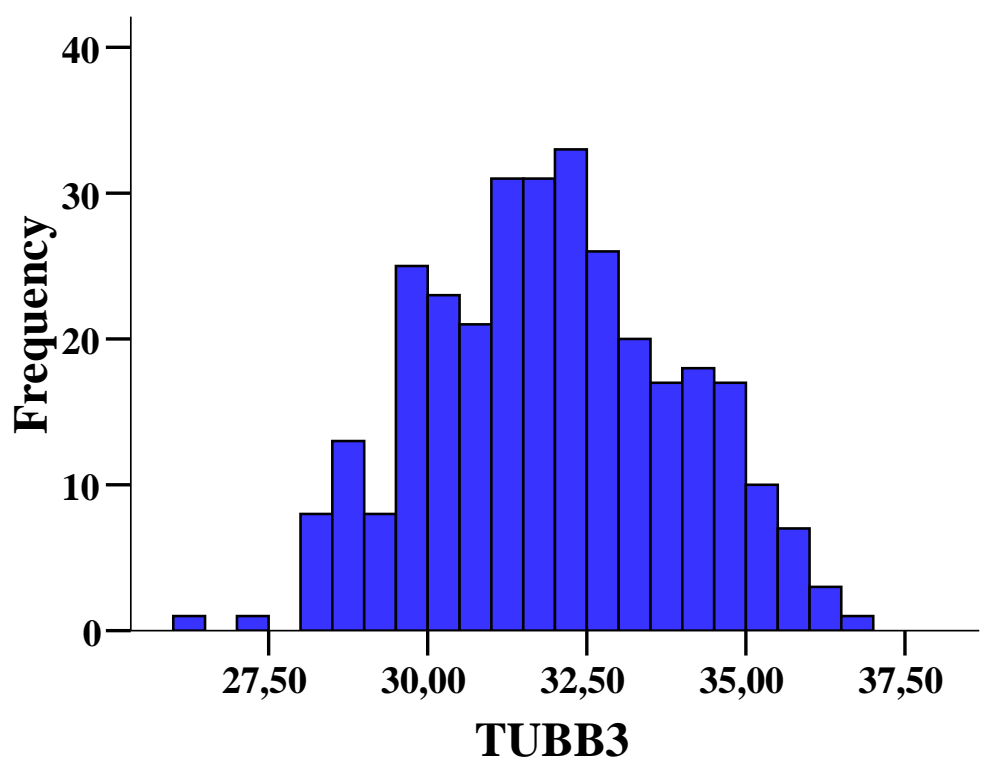


Figure 3. Immunohistochemical expression of TUBB3 in breast carcinomas.

A. High grade breast adenocarcinoma showed moderate to intense cytoplasmic staining (score $2+$ and $3+$ ) with anti-class III $\beta$-tubulin (TUBB3); Note the intense staining of tumor cells at the vessel lumen (arrows); B. Absence of TUBB3 expression (score 0) on tumor cells, whereas the endothelial cells, which served as internal control, stained positive. (DAB X 40)

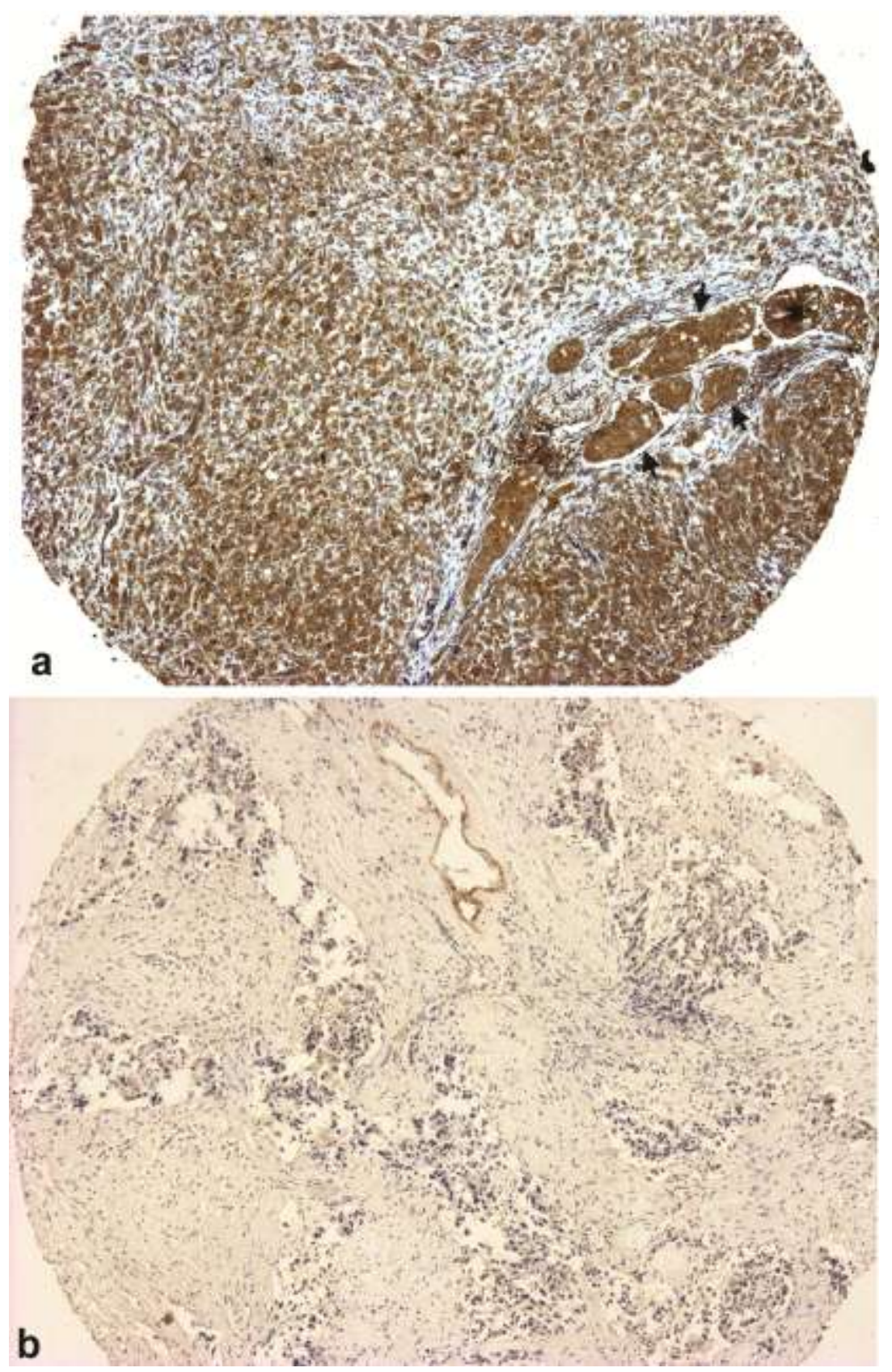


Figure 4. Boxplots of TUBB3 mRNA expression according to TUBB3 protein expression. Positive TUBB3 protein expression is associated with higher levels of TUBB3 mRNA (Mann Whitney p<0.001).

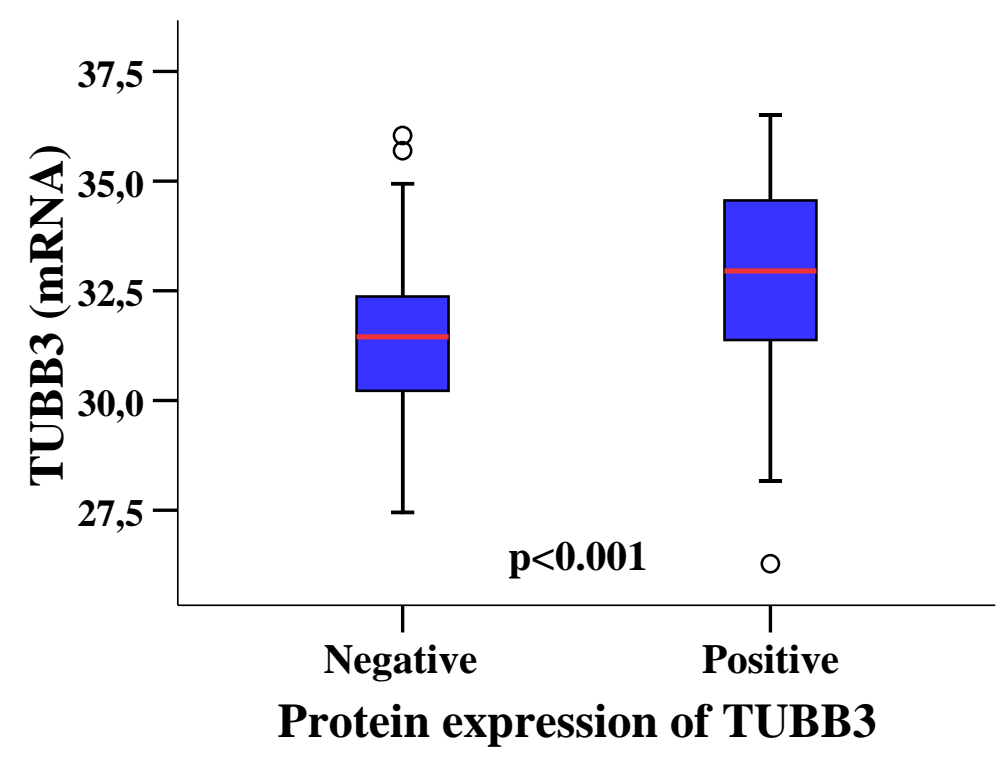


Figure 5. DFS (a) and OS (b) Kaplan-Meier curves by TUBB3 mRNA status.

(a)

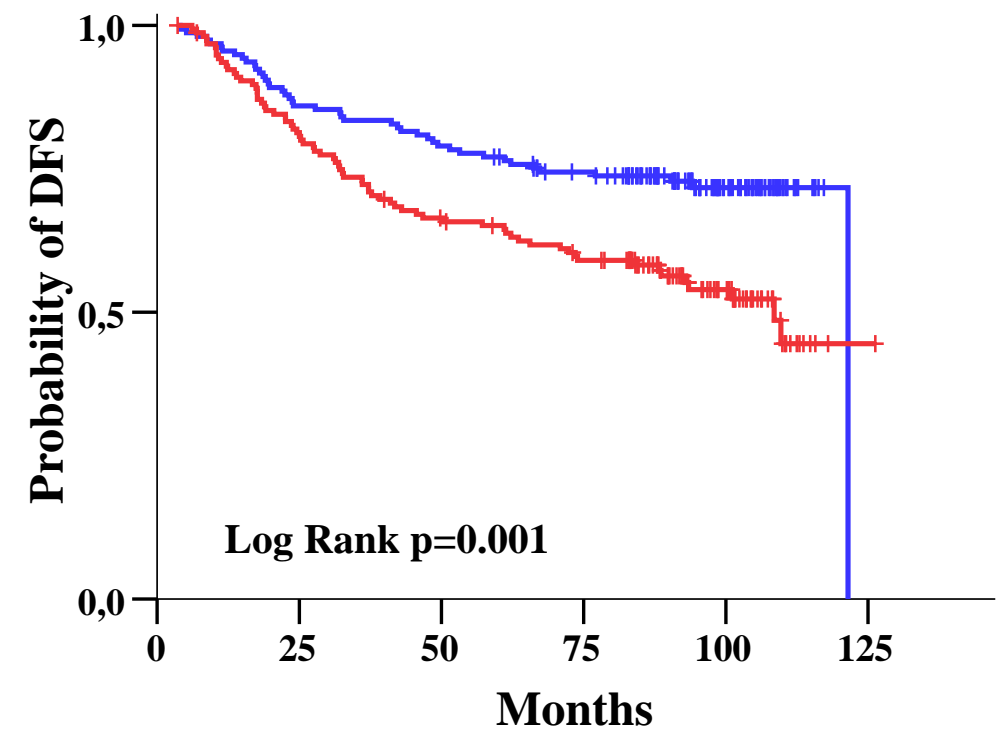

(b)

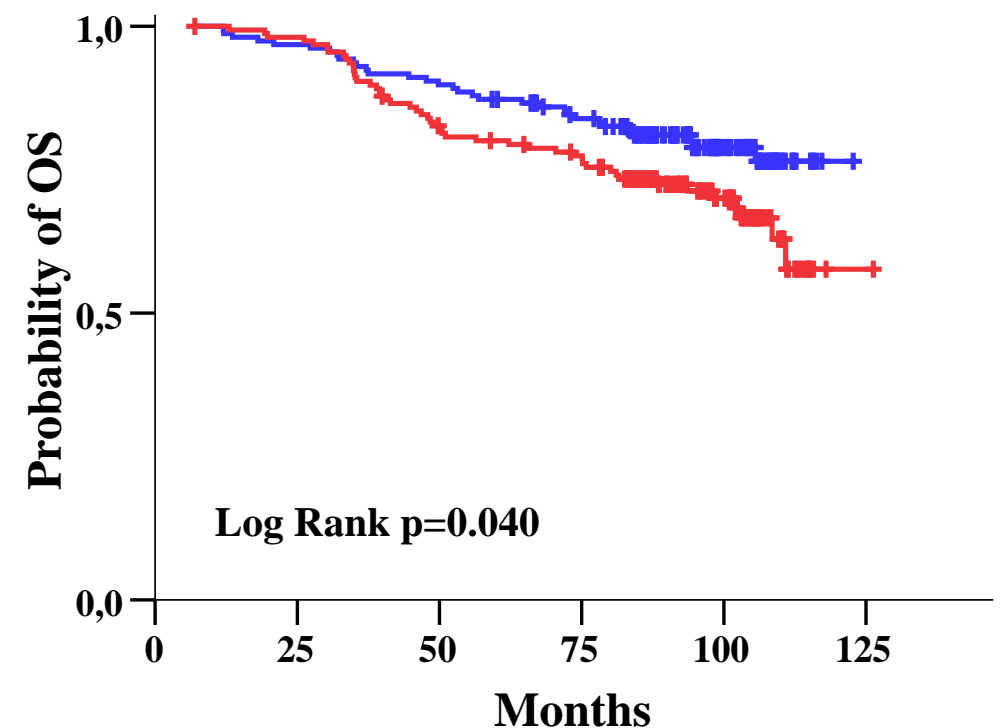

Low tumour TUBB3 mRNA

High tumour TUBB3 mRNA 
Figure 6. OS (left) and DFS (right) for E-T-CMF and E-CMF in TUBB3 mRNAlow and high patients.

(a) TUBB3 mRNA-low
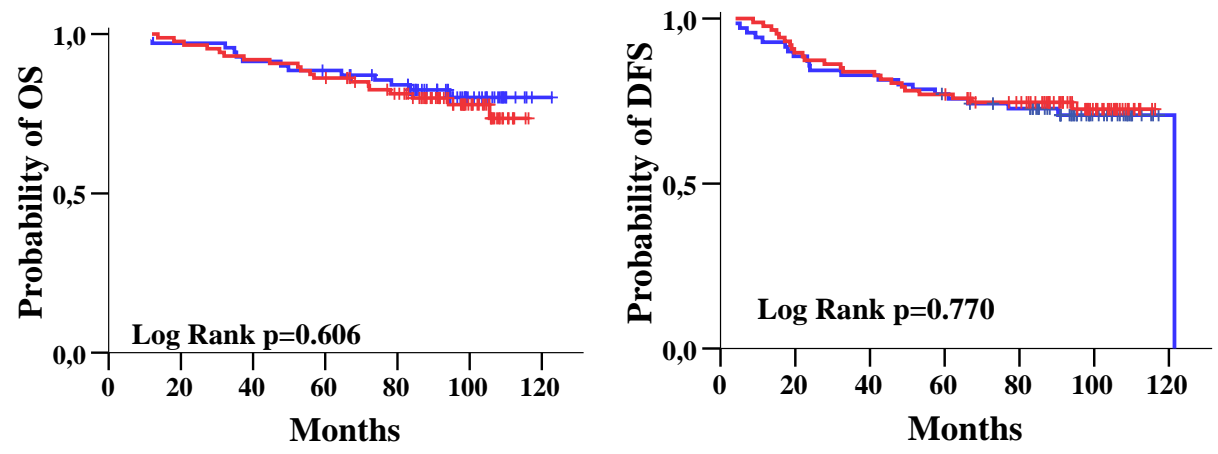

(b) TUBB3 mRNA-high
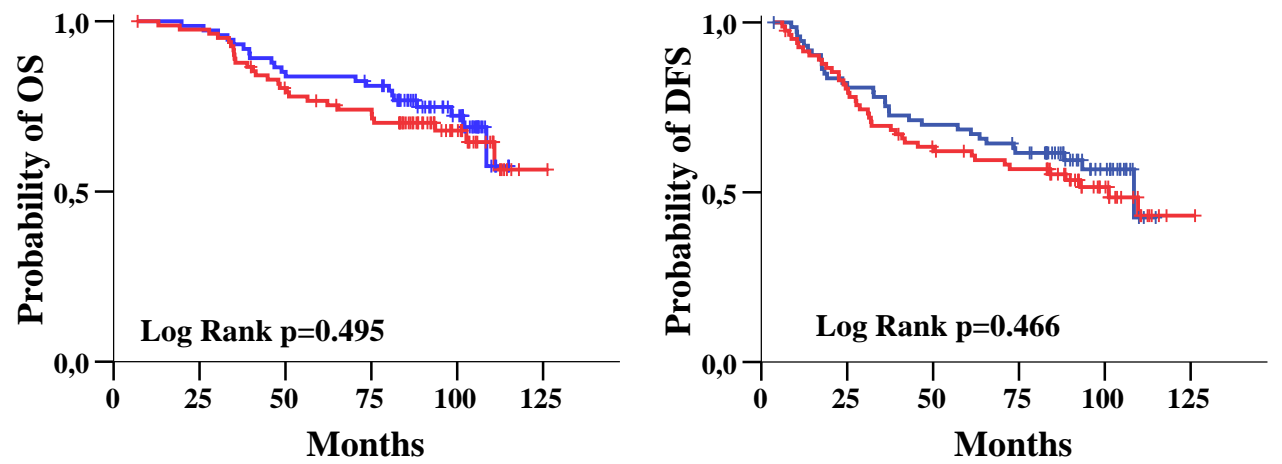

E-T-CMF

$\mathrm{E}-\mathrm{CMF}$ 
Figure 7. OS (left) and DFS (right) for E-T-CMF and E-CMF in TUBB3 mRNAlow and high patients restricted to ER IHC-negative tumours.

(a) TUBB3 mRNA-Iow
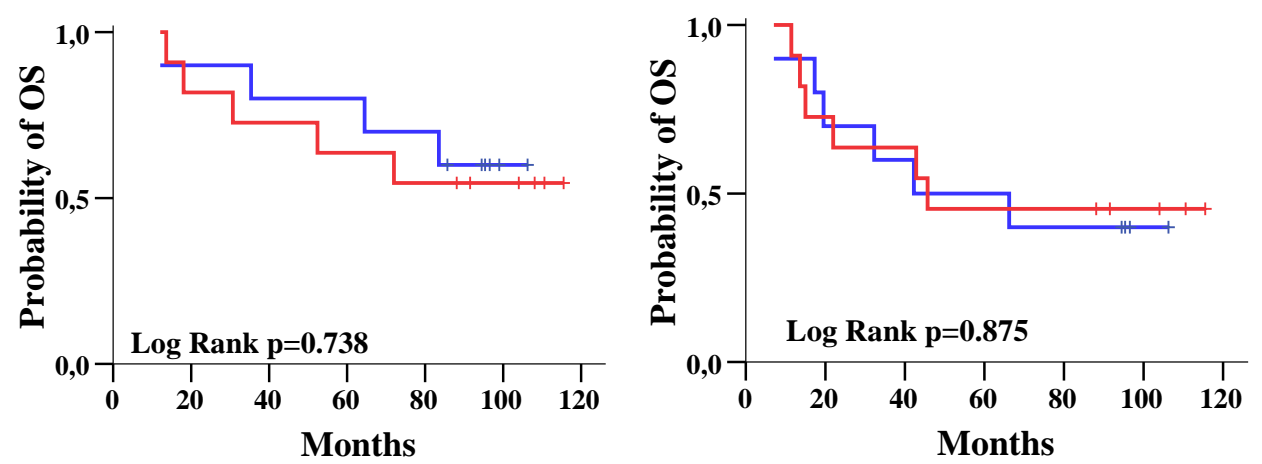

(b) TUBB3 mRNA-high
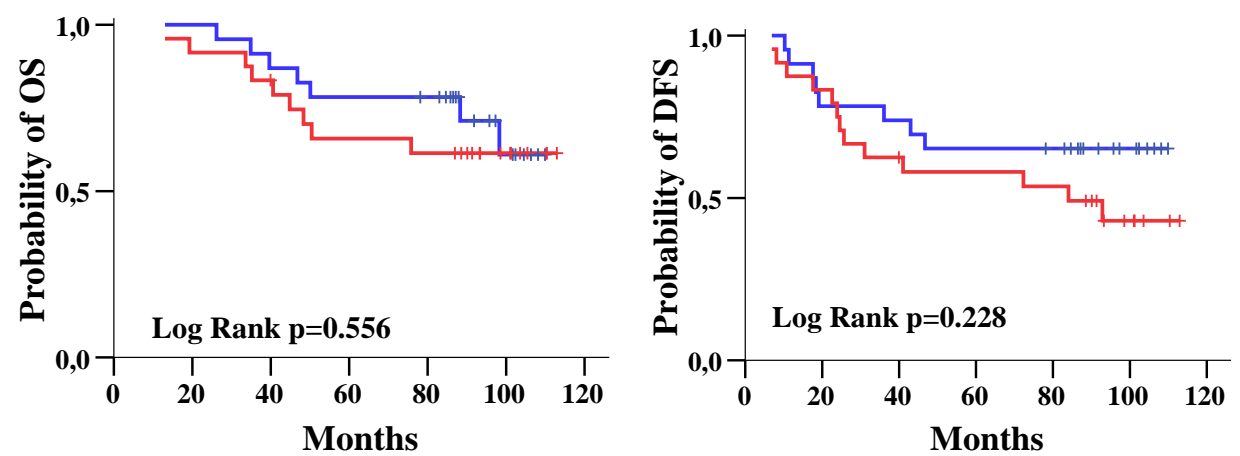

$\begin{array}{ll}\text { E-T-CMF } & - \\ \text { E-CMF } & -\end{array}$

